\title{
Perbandingan Uji Aktivitas Antibakteri Umbi Bawang Merah (Allium Cepa L) Dan Umbi Bawang Putih (Allium Sativum) Terhadap Pertumbuhan Bakteri Shigella Dysenteriae
}

\author{
Fahrurrozi Hari Purnomo $\mathbf{S}^{1}$, Avin Ainur Fitrianingsih², Zainabur Rahmah ${ }^{3}$, Alvi \\ Milliana $^{2}$
}

\begin{abstract}
${ }^{1}$ Program Studi Pendidikan Dokter, Fakultas Kedokteran dan Ilmu Kesehatan UIN Maulana Malik Ibrahim Malang ${ }^{2}$ Departemen Mikrobiologi, Fakutas Kedokteran dan Ilmu Kesehatan UIN Maulana Malik Ibrahim Malang ${ }^{3}$ Departemen Parasitologi, Fakutas Kedokteran dan Ilmu Kesehatan UIN Maulana Malik Ibrahim Malang
\end{abstract}

\begin{tabular}{|c|c|}
\hline & $A b s t r a c t$ \\
\hline $\begin{array}{l}\text { Keyword: } \\
\text { bacterial } \\
\text { growth } \\
\text { garlic extract; } \\
\text { red onion; } \\
\text { Shigella } \\
\text { dysenteriae }\end{array}$ & 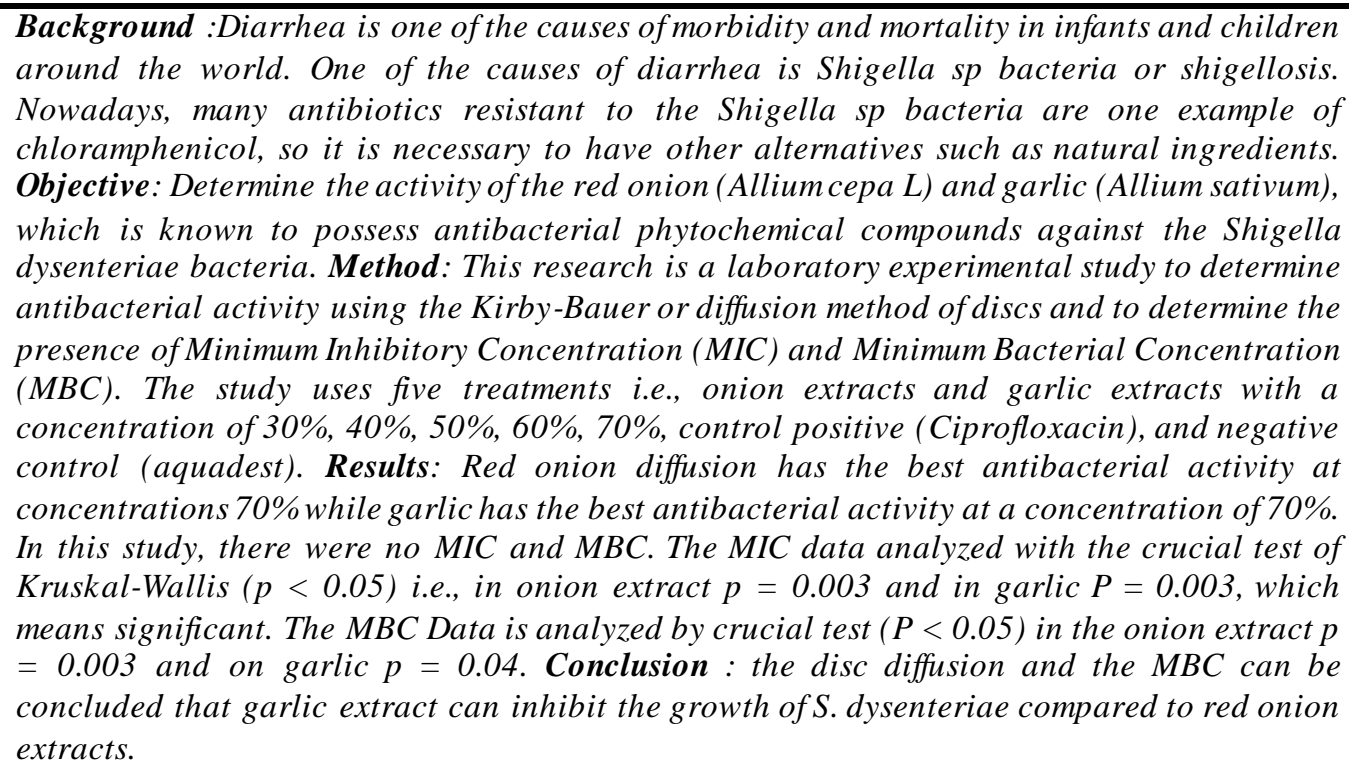 \\
\hline
\end{tabular}

Kata kunci :

ekstrak

bawang

merah;

ekstrak

bawang putih; pertumbuhan bakteri;

Shigella

dysenteriae

\begin{abstract}
A B S T RA K
Latar Belakang : Diare merupakan salah satu penyebab morbiditas dan mortalitas pada bayi dan anak anak di seluruh dunia. Salah satu penyebab diare adalah bakteri Shigella sp atau shigellosis. Saat ini banyak antibiotik yang resisten terhadap bakteri shigella sp ini salah s atu contohnya adalah kloramfenikol sehingga diperlukan adanya alternatif lain seperti bahan alami. Tujuan : Mengetahui perbandingan aktivitas dari umbi bawang merah (Allium cepa L) dan Umbi bawang putih (Allium sativum) yang diketahui memliki senyawa fitokimia antibakteri terhadap bakteri Shigella dysenteriae. Metode: Penelitian ini merupakan penelitian eksperimental laboratorium untuk menentukan aktivitas antibakteri menggunakan metode Kirrby-bauer atau diffusi cakram serta untuk menentukan Konsentrasi Hambat Minimum (KHM) dan Konsentrasi Bunuh Minimum (KBM). Menggunakan empat belas perlakuan yaitu ekstrak Bawang Merah dan ekstrak Bawang Putih dengan konsentrasi 30\%, 40\%, 50\%, 60\%, 70\%, kontrol positif (Ciprofloxacin), dan control negative (aquadest). Hasil yang diperoleh dari penelitian ini yaitu hasil diffusi cakram bawang merah memiliki aktivitas antibakteri terbaik pada konsentrasi $70 \%$ sedangkan pada bawang putih memiliki aktivitas antibakteri terbaik pada konsentrasi $70 \%$. Pada penelitian ini tidak didapatkan adanya KHM dan KBM. Data KHM dianalisis dengan uji Kruskal-Wallis $(\mathrm{p}<0,05)$ yakni pada ekstrak bawang merah $\mathrm{p}$ $=0,003$ dan bawang putih $\mathrm{p}=0,003$ yang berarti signifikan. Data KBM dianalisis dengan uji Kruskal-Wallis $(\mathrm{p}<0,05)$ yakni pada ekstrak bawang merah $\mathrm{p}=0,003$ dan pada bawang putih $\mathrm{p}=0,004$. Kesimpulan : esktrak bawang putih lebih mampu menghambat pertumbuhan $S$. dysenteriae dibandingkan ekstrak bawang merah.
\end{abstract}

* Corresponding author

Email: fahrurrozi.purnomo@gmail.com 


\section{PENDAHULUAN}

Diare merupakan salah satu penyebab utama morbiditas dan mortalitas pada bayi dan anak- anak di seluruh dunia. Pada negara berkembang diperkirakan $17,5 \%$ $21 \%$ dari semua kematian anak di bawah usia 5 tahun disebabkan oleh diare, setara dengan 1,5 juta kematian tiap tahun [1] .

Salah satu penyeb diare adalah disentri basiler. Penyakit disentri basiler atau shigellosis disebabkan oleh infeksi bakteri Shigella sp [2]. Shigella merupakan bakteri berbentuk basil non motil, gram negatif, dan termasuk kedalam famili enterobacteriaceae. Terdapat empat jenis bakteri Shigella yaitu Shigella dysenteriae, Shigella flexnerii, Shigella sonnei, dan Shigella boydii tetapi yang dapat menimbulkan manifestasi paling berat adalah $S$. dysenteriae [3]. $S$ dysenteriae dapat menimbulkan manifestasi yang berat karena mempunyai toksin yang secara struktural dan genetik sangat mirip dengan toksin E.coli, yaitu Shiga toxins tipe 1 dan 2 [4]. Manusia yang terinfeksi S. dysenteriae akan mengalami gejala klinis secara mendadak seperti pengeluaran feses secara terus menerus, berlendir dan berdarah, serta keinginan untuk buang air besar yang sering [3].

Terapi yang dapat diberikan pada infeksi oleh $S$. dysenteriae adalah antibiotik [3]. Antibiotik yang dapat diberikan misalnya ciprofloxacin dan azhitromycin tetapi penggunaannya masih kontroversi dikarenakan resistensi antibiotik yang semakin meluas [4]. Terapi disentri basiller menggunakan antibiotik Kloramfenikol dan Tetrasiklin sudah tidak efektif hal tersebut dikarenakan transfer secara horizontal dan penyebaran klonal strain terutama melalui transposon dan plasmid [3].

Keanekaragaman hayati yang ada di Indonesia salah satunya adalah tumbuhan yang bermanfaat bagi manusia sebagai contoh bawang putih (Allium sativum) dan bawang merah (Allium cepa L).
Pada spesies bawang atau Allium $s p$ mengandung sulfur yang memberikan aroma dan rasa pada bawang. Penelitian sebelumnya menyebutkan bahwa Allium $s p$ memiliki beberapa manfaat seperti antimikroba, antioxidan, antifungal, dll [5]. Ekstrak bawang diketahui memiliki Diallyl thiosulfida (Allisin) adapun thiosulfida lain yang terdapat pada bawang adalah allyl methyl-methyl allyl- dan trans-1 propenyl thiosulfinate yang tidak stabil di alam[6]. Antibakteri allicin ini bekerja dengan mengubah protein, lipid dan polisakarida pada membran sel bakteri sehingga dapat mereduksi sistein di dalam mikroba dimana sistein memerankan hal penting dalam biogenesis pada ikatan $\mathrm{Fe}-\mathrm{S}$ yang ditemukan pada beberapa bagian katalitik di sebagian enzim dan protein, sistein juga berperan untuk melindungi sel dari stres oksidatif, selain itu allicin juga dapat mengganggu ikatan disulfide pada proteinnya [7],(8], Sedangkan pada bawang merah diketahui terdapat senyawa flavanoid yang berpotensi tinggi sebagai antibakteri [9].

$$
\text { Penelitian sebelumnya yang }
$$

menggunakan ekstrak bawang merah (Allium cepa L) dan ekstrak bawang putih (Allium sativum) sebagai antibiotik dengan konsentrasi $50 \%$ mempunyai efek antibakterial terhadap Staphylococcus aureus [10]. Penelitian dari Degirmencioglu dan Irkin (2009) mengatakan bahwa ekstrak bawang putih dan bawang merah dengan pelarut air dan diethyleter mampu menghambat pertumbuhan beberapa jenis bakteri dan jamur yaitu Enterobacter aerogenes, Escherichia coli, Salmonella enteritidis, Salmonella typhimurium, Staphylococcus aureus, Bacillus subtilis, dan jamur Candida albicans [11].

Berdasarkan uraian diatas diperlukan penelitian tentang ekstrak bawang putih (Allium sativum) dan bawang merah (Allium cepa L) terhadap pertumbuhan bakteri $S$. dysenteriae. 
METODE

Penelitian ini dilakukan pada bulan Desember 2019 - Mei 2020 di Laboratorium Mikrobiologi dan Laboratorium Fitokimia Fakultas Kedokteran dan Ilmu Kesehatan UIN Maulana Malik Ibrahim Malang. Bakteri yang digunakan dalam penelitian ini adalah S.dysenteriae yang didapatkan dari isolate murni dari Lab Mikrobiologi Fakultas Kedokteran Universitas Brawijaya, diinkubasi dengan suhu $37{ }^{\circ} \mathrm{C}$ selama 24 jam. Penelitian ini menggunakan sampel yang dilakukan pengulangan dengan rumus (t-1) $(\mathrm{n}-1) \geq 15$ dimana $\mathrm{t}$ adalah banyak sample, dan $\mathrm{n}$ adalah banyaknya pengulangan. Perhitungan dilakukan seperti berikut:

$$
\begin{aligned}
& (\mathrm{t}-1)(\mathrm{n}-1) \quad \geq 15 \\
& \text { (10-1) (n-1) } \geq 15 \\
& \text { 9n-9 } \quad \geq 15 \\
& \text { 9n } \geq 24 \\
& \mathrm{n} \quad \geq 2,6 \rightarrow 3
\end{aligned}
$$

Sampel menggunakan 5 sampel dari ekstrak bawang merah dan 5 sampel dari ekstrak bawang puth dengan konsentrasi $30 \%, 40 \%, 50 \%, 60 \%$ dan $70 \%$ dan 2 jenis kontrol, yakni kontrol positif (antibiotik cipofloxacin) dan kontrol negatif (pelarut) sehingga masing-masing dilakukan 3 kali pengulangan.

\section{Prosedur Penelitian}

\section{Pembuatan Ekstrak Bawang Merah dan Bawang Putih}

Pembuatan ekstrak umbi bawang merah dan bawang putih menggunakan metode ( Ultrasonic Asissted Extraction) UEA dengan pelarut etanol 96\%. Ekstraksi dari umbi bawang merah dan bawang putih dengan pelarut etanol $96 \%$ dengan perbandingan 1 : $10 . \quad$ Selanjutnya dimasukkan ke dalam ekstraksi ultrasonik dengan frekuensi $42 \mathrm{kHz}$ dengan suhu kamar selama 10-30 menit. Hasil dari ekstrak ini kemudian diuapkan dengan Rotary Evaporator hingga diperoleh ekstrak kental [12].

Ekstrak kental kemudian diencerkan menggunakan berbagai konsentrasi pengenceran untuk mengetahui berbagai macam konsentrasi yang dapat menghambat pertumbuhan bakteri S. dysenteriae. Konsentrasi yang diperlukan dalam penelitian ini yaitu $70 \%, 60 \%, 50 \%, 40$ $\%, 30 \%$.

\section{Uji Aktivitas Antibakteri}

Uji aktivitas ini dilakukan dengan 2 metode, yakni metode difusi cakram (KirbyBauer) dan metode dilusi tabung. Metode difusi cakram dilakukan dengan cara antibakteri fraksi yang akan diuji diserapkan pada kertas cakram dan diletakkan di atas media Mueller-Hinton Agar (MHA). Metode dilusi tabung ini dilakukan untuk mengetahui Kadar Hambat Minimal (KHM) dari ekstrak bawang merah (Allium cepa L) dan ekstrak bawang putih (Allium sativum) terhadap $S$. dysenteriae menggunakan 12 tabung reaksi dengan masing-masing konsentrasi ekstrak bawang merah dan bawang putih $30 \%-70 \%$.

\section{Pengukuran Diameter Zona Hambat}

Metode pengukuran zona hambat pada ekstrak bawang merah atau bawang putih dengan konsentrasi $70 \mathrm{mg} / \mathrm{ml}, 60 \mathrm{mg} / \mathrm{ml}, 50$ $\mathrm{mg} / \mathrm{ml}, 40 \mathrm{mg} / \mathrm{ml}, 30 \mathrm{mg} / \mathrm{ml}$ kontrol + , dan Kontrol - dengan metode difusi cakram Kirby-Bauer. Perhitungan dilakukan pada zona hambat atau zona inhibisi yaitu zona bening (clear zone) yang terbentuk di sekitar kertas cakram yang mengandung ekstrak bawang merah (Allium cepa L) dan ekstrak bawang putih (Allium sativum).

\section{Pengukuran KHM dan KBM}

Pengukuran KHM dilihat dari kekeruhan atau turbiditas yang dinilai pada masing-masing tabung. Sedangkan pengukuran $\mathrm{KBM}$ dimulai dari hasil dilusi tabung diambil sebanyak $100 \mu \mathrm{L}$ lalu ditambahkan $10 \mathrm{~mL}$ MHA, setelah itu di sebar menggunakan spreader hingga ekstrak yang mengandung bakteri dan MHA tercampur rata, setelah itu menyimpannya di dalam inkubator selama 18-24 jam dengan suhu $37^{\circ} \mathrm{C}$. Dilakukan perhitungan jumlah koloni pada media Muller Hinton Agar (MHA). Perhitungan dari KBM menggunakan alat colony counter dengan satuan CFU /ml cairan ( Colony Forming Unit ). Setiap 1 sel bakteri dalam perhitungan akan menjadi 1 koloni dan jika 
bersinggungan akan dihitung sebagai 2 koloni.

\section{HASIL}

\section{Hasil Pengukuran Diameter Zona Hambat Ekstrak Bawang Merah dan Putih}

Hasil perbandingan pengukuran diameter zona hambat ekstrak bawang merah adn bawang putih terhadap bakteri $S$. dysenteriae pada konsentrasi $70 \%, 60 \%$, $50 \%$, 40\%, 30\%, kontrol positif, dan kontrol negatif dengan metode difusi cakram KirbyBauer dapat dilihat pada tabel 1 .

\section{Hasil Pengukuran KHM S. dysenteriae Ekstrak Bawang Merah dan Putih}

Hasil perbandingan pertumbuhan koloni $S$. dysenteriae ekstrak bawang merah dan bawang putih pada konsentrasi $70 \%, 60 \%$, $50 \%, 40 \%, 30 \%$, kontrol positif, dan kontrol negatif dapat dilihat pada tabel 2 .
Hasil Pengukuran KBM S. dysenteriae Ekstrak Bawang Merah dan Putih

Hasil perbandingan pertumbuhan koloni S. dysenteriae ekstrak bawang merah dan bawang putih pada konsentrasi $70 \%, 60 \%$, $50 \%, 40 \%, 30 \%$, kontrol positif, dan kontrol negatif dapat dilihat pada tabel 3 .

\section{Analisis Deskriptif dan Diameter Zona Hambat Rata-Rata Konsentrasi Bunuh Minimun $S$. dysenteriae Berdasarkan Pemberian Ekstrak Bawang Merah dan Putih}

Berdasarkan pengolahan statistik dari hasil pengukuran pertumbuhan koloni $S$. dysenteriae dan diameter zona hambat pada 7 kelompok yaitu kelompok kontrol positif (+), kelompok kontrol negatif (-), serta kelompok perlakuan yang terdiri dari 5 dosis yaitu 30\%, 40\%, 50\%, 60\%, 70\% didapatkan hasil grafik 1 menginformasikan bahwa pada kelompok kontrol negatif, yaitu kelompok yang hanya diberi pelarut tidak.

Tabel 1. Hasil Pengukuran Diameter Zona Hambat Ekstrak Bawang Merah dan Puth

\begin{tabular}{|c|c|c|c|c|}
\hline \multirow[t]{2}{*}{ No. } & \multirow[t]{2}{*}{ Kode Sampel } & \multirow[t]{2}{*}{ Perlakuan } & \multicolumn{2}{|c|}{$\begin{array}{c}\text { Diameter Zona Hambat } \\
(\mathrm{mm})\end{array}$} \\
\hline & & & Ekstrak Bawang Merah & Ekstrak Bawang Putih \\
\hline 1 & $\mathrm{~K}+1$ & 1 & 31 & 31 \\
\hline 2 & $\mathrm{~K}+2$ & 1 & 31 & 32 \\
\hline 3 & $\mathrm{~K}+3$ & 1 & 31 & 32 \\
\hline 4 & $\mathrm{~K}-1$ & 2 & 0 & 0 \\
\hline 5 & $\mathrm{~K}-2$ & 2 & 0 & 0 \\
\hline 6 & $\mathrm{~K}-3$ & 2 & 0 & 0 \\
\hline 7 & Konsentrasi $30 \%-1$ & 3 & 0 & 0 \\
\hline 8 & Konsentrasi $30 \%-2$ & 3 & 0 & 0 \\
\hline 9 & Konsentrasi $30 \%-3$ & 3 & 0 & 0 \\
\hline 10 & Konsentrasi $40 \%-1$ & 4 & 0 & 6,1 \\
\hline 11 & Konsentrasi $40 \%-2$ & 4 & 0 & 0 \\
\hline 12 & Konsentrasi $40 \%-3$ & 4 & 0 & 0 \\
\hline 13 & Konsentrasi $50 \%-1$ & 5 & 0 & 6,6 \\
\hline 14 & Konsentrasi $50 \%-2$ & 5 & 0 & 6,4 \\
\hline 15 & Konsentrasi $50 \%-3$ & 5 & 0 & 6,4 \\
\hline 16 & Konsentrasi $60 \%-1$ & 6 & 0 & 7,6 \\
\hline 17 & Konsentrasi $60 \%-2$ & 6 & 0 & 6,6 \\
\hline 18 & Konsentrasi $60 \%-3$ & 6 & 0 & 6,6 \\
\hline 19 & Konsentrasi $70 \%-1$ & 7 & 6,8 & 9,5 \\
\hline 20 & Konsentrasi $70 \%-2$ & 7 & 6,8 & 7,2 \\
\hline 21 & Konsentrasi $70 \%-3$ & 7 & 6,8 & 7,2 \\
\hline
\end{tabular}


Perbandingan uji aktivitas antibakteri umbi bawang merah (Alium cepa l) dan umbi bawang puth (Allium sativum) terhadap pertumbuhan bakteri shigella dysenteriae

Tabel 2. Hasil Konsentrasi Hambat Minimum $S$ dysenteriae Ekstrak Bawang Merah dan Putih

\begin{tabular}{|c|c|c|c|c|}
\hline \multirow{2}{*}{ No. } & \multirow{2}{*}{ Kode Sampel } & \multirow{2}{*}{ Perlakuan } & \multicolumn{2}{|c|}{$\begin{array}{l}\text { Diameter Zona Habat } \\
(\mathrm{mm})\end{array}$} \\
\hline & & & Ekstrak Bawang Merah & Ekstrak Bawang Putih \\
\hline 1 & $\mathrm{~K}+1$ & 1 & Pekat & Pekat \\
\hline 2 & $\mathrm{~K}+2$ & 1 & Pekat & Pekat \\
\hline 3 & $\mathrm{~K}+3$ & 1 & Pekat & Pekat \\
\hline 4 & $\mathrm{~K}-1$ & 2 & Keruh & Keruh \\
\hline 5 & $\mathrm{~K}-2$ & 2 & Keruh & Keruh \\
\hline 6 & $\mathrm{~K}-3$ & 2 & Keruh & Keruh \\
\hline 7 & Kons entrasi 30\% - 1 & 3 & Coklat Keruh & Coklat Keruh \\
\hline 8 & Konsentrasi 30\% - 2 & 3 & Coklat Keruh & Coklat Keruh \\
\hline 9 & Kons entrasi 30\% - 3 & 3 & Coklat Keruh & Coklat Keruh \\
\hline 10 & Kons entrasi $40 \%-1$ & 4 & Coklat Keruh & Coklat Keruh \\
\hline 11 & Konsentrasi $40 \%$ - 2 & 4 & Coklat Keruh & Coklat Keruh \\
\hline 12 & Kons entrasi $40 \%-3$ & 4 & Coklat Keruh & Coklat Keruh \\
\hline 13 & Konsentrasi $50 \%-1$ & 5 & Coklat Keruh & Coklat Keruh \\
\hline 14 & Konsentrasi $50 \%-2$ & 5 & Coklat Keruh & Coklat Keruh \\
\hline 15 & Konsentrasi $50 \%-3$ & 5 & Coklat Keruh & Coklat Keruh \\
\hline 16 & Konsentrasi $60 \%-1$ & 6 & Coklat Keruh & Coklat Keruh \\
\hline 17 & Konsentrasi $60 \%$ - 2 & 6 & Coklat Keruh & Coklat Keruh \\
\hline 18 & Konsentrasi $60 \%-3$ & 6 & Coklat Keruh & Coklat Keruh \\
\hline 19 & Konsentrasi $70 \%-1$ & 7 & Coklat Keruh & Coklat Keruh \\
\hline 20 & Konsentrasi $70 \%-2$ & 7 & Coklat Keruh & Coklat Keruh \\
\hline 21 & Kons entrasi $70 \%-3$ & 7 & Coklat Keruh & Coklat Keruh \\
\hline
\end{tabular}

Tabel 3. Hasil Pengukuran Pertumbuhan Koloni $S$ dysenteriae Ekstrak Bawang Merah dan Putih

\begin{tabular}{|c|c|c|c|c|}
\hline \multirow[t]{2}{*}{ No. } & \multirow[t]{2}{*}{ Kode Sampel } & \multirow[t]{2}{*}{ Perlakuan } & \multicolumn{2}{|c|}{$\begin{array}{l}\text { Pertumbuhan Koloni } S . \text { dysenteriae } \\
(\mathrm{CFU} / \mathrm{ml})\end{array}$} \\
\hline & & & Ekstrak Bawang Merah & Ekstrak Bawang Putih \\
\hline 1 & $\mathrm{~K}+1$ & 1 & 0 & 0 \\
\hline 2 & $\mathrm{~K}+2$ & 1 & 0 & 0 \\
\hline 3 & $\mathrm{~K}+3$ & 1 & 0 & 0 \\
\hline 4 & K-1 & 2 & 134 & 212 \\
\hline 5 & $\mathrm{~K}-2$ & 2 & 202 & 218 \\
\hline 6 & K-3 & 2 & 202 & 218 \\
\hline 7 & Konsentrasi $30 \%-1$ & 3 & 63 & 84 \\
\hline 8 & Kons entrasi $30 \%-2$ & 3 & 57 & 98 \\
\hline 9 & Konsentrasi $30 \%-3$ & 3 & 57 & 98 \\
\hline 10 & Konsentrasi $40 \%-1$ & 4 & 57 & 71 \\
\hline 11 & Konsentrasi $40 \%$ - 2 & 4 & 50 & 74 \\
\hline 12 & Konsentrasi $40 \%-3$ & 4 & 50 & 74 \\
\hline 13 & Konsentrasi $50 \%-1$ & 5 & 37 & 62 \\
\hline 14 & Konsentrasi $50 \%-2$ & 5 & 41 & 68 \\
\hline 15 & Konsentrasi $50 \%-3$ & 5 & 41 & 68 \\
\hline 16 & Konsentrasi $60 \%-1$ & 6 & 32 & 50 \\
\hline 17 & Konsentrasi $60 \%$ - 2 & 6 & 36 & 51 \\
\hline 18 & Kons entrasi $60 \%-3$ & 6 & 36 & 51 \\
\hline 19 & Konsentrasi $70 \%-1$ & 7 & 25 & 49 \\
\hline 20 & Konsentrasi $70 \%$ - 2 & 7 & 28 & 48 \\
\hline 21 & Konsentrasi $70 \%-3$ & 7 & 28 & 48 \\
\hline
\end{tabular}

Keteragan : K+ : Kontrol positif, K- : Kontrol Negatif ,Konsentrasi -1 : Pengulangan pertama, Konsentrasi -2 : Pegulangan kedua, Konsentrasi-3: Pengulangan ketiga 
Tabel 4. Hasil Uji Mann Whitney Diameter Zona Hambat Pemberian Ekstrak Bawang Merah dan Bawang Putih

\begin{tabular}{ccccccc}
\hline & & \multicolumn{5}{c}{ Ekstrak Bawang } \\
\cline { 3 - 6 } & & Kons 30\% & Kons 40\% & Kons 50\% & Kons 60\% & Kons 70\% \\
\hline \multirow{3}{*}{ Ekstrak } & Kons 30\% & 1,000 & 1,000 & 0,034 & 1,000 & 0,025 \\
Bawang Putih & Kons 40\% & 0,317 & 0,317 & 0,317 & 0,317 & 0,034 \\
& Kons 50\% & 0,034 & 0,034 & 0,034 & 0,034 & 0,034 \\
& Kons 60\% & 0,034 & 0,034 & 0,034 & 0,034 & 0,480 \\
& Kons 70\% & 0,034 & 0,034 & 0,034 & 0,034 & 0,034 \\
\hline
\end{tabular}

Tabel 5. Hasil Uji Post Hoc Tukey HSD Konsentrasi Bunuh Minimal Pemberian Ekstrak Bawang Merah dan Bawang Puth

\begin{tabular}{llccccc}
\hline & & \multicolumn{5}{c}{ Ekstrak Bawang Putih } \\
\cline { 3 - 7 } & & Kons 30\% & Kons 40\% & Kons 50\% & Kons 60\% & Kons 70\% \\
\hline \multirow{2}{*}{ Ekstrak } & Kons 30\% & 0,000 & 0,000 & 0,000 & 0,000 & 0,000 \\
Kawang & Kons 40\% & 0,002 & 0,000 & 0,000 & 0,000 & 0,000 \\
Merah & Kons 60\% & 0,101 & 0,001 & 0,000 & 0,000 & 0,000 \\
& Kons 70\% & 0,128 & 1,000 & 0,018 & 0,000 & 0,000 \\
& 0,023 & 0,889 & 0,101 & 0,002 & 0,000 \\
\hline
\end{tabular}

dihasilkan diameter zona hambat. Pada kelompok kontrol positif yaitu pemberian antibiotik ciprofloxacin dihasilkan ratarata diameter zona hambat paling tinggi pada semua kelompok perlakuan dimana pada pemberian ekstrak bawang putih nilai rata-rata yang diperoleh lebih tinggi sedikit bila dibandingkan dengan pemberian ekstrak bawang merah. Kemudian pada konsentrasi $30 \%$ hingga $60 \%$ tidak dihasilkan dimater zona hambat pada pemberian ekstrak bawang merah. Dan pada konsentrasi $70 \%$, pemberian ekstrak bawang puth menghasilkan diameter zona hambat lebih tinggi dari pada ekstrak bawang merah. Berdasarkan nilai mean pemberian ekstrak bawang puth menghasilkan trend diameter zona hambat yang meningkat seiring bertambahnya konsentrasi ekstrak.

Sedangkan untuk hasil dari KBM dilihat dari grafik 2 menginformasikan rata-rata pertumbuhan koloni Shigella dysenteriae pada 7 kelompok dimana diketahui untuk kelompok perlakuan kontrol positif yaitu pemberian antibiotik ciprofloxacin, tidak ada koloni Shigella dysenteriae yang tumbuh. Kemudian pada kelompok kontrol negatif atau yang hanya diberikan pelarut dihasilkan rata-rata pertumbuhan koloni yang lebih tinggi.
Namun kedua ekstrak ini belum ada yang mencapai KBM

\section{Hasil Analisis Data Perbandingan Ekstrak Bawang Merah dan Bawang Putih}

Hasil uji efek antibakteri pemberian ekstrak bawang merah dan bawang putih terhadap bakteri $S$ dysenteriae dilakukan analisa menggunakan uji Post Hoc Mann Whitney untuk mengetahui perbedaan pengaruh antar masing-masing kelompok perlakuan terhadap diameter zona hambat dapat dilihat pada tabel.4 dan Post Hoc Tukey pada pertumbuhan koloni bakteri S.dysenteriae dapat dilihat di tabel 5 .

Hasil analisis tabel 4 menunjukkan bahwa antar kelompok ekstrak bawang puth $30 \%$ menghasilkan perbedaan diameter zona hambat yang signifikan pada ekstrak bawang merah $50 \%$ dan $70 \%$ - Pada kelompok ekstrak bawang putih $40 \%$ menghasilkan perbedaan diameter zona hambat yang signifikan hanya pada ekstrak bawang merah 70\%. Pada kelompok ekstrak bawang putih 50\% menghasilkan perbedaan diameter zona hambat yang signifikan pada semua kelompok perlakuan demikian pula pada kelompok konsentrasi $70 \%$. Sedangkan pada konsentrasi ekstrak bawang merah 
$70 \%$ dihasilkan perbedaan yang tidak signifikan hanya dengan ekstrak bawang putih $60 \%$ (gambar 1).

Hasil analisis tabel 5 menunjukkan bahwa pada kelompok ekstrak bawang merah $30 \%$ dan $40 \%$ menghasilkan perbedaan pertumbuhan koloni bakteri S.dysenteriae yang signifikan dengan semua konsentrasi ekstrak bawang puth. Kemudian pada ekstrak bawang merah $50 \%$ ditemukan tidak adanya perbedaan dengan ekstrak bawang puth $30 \%$. Kemudian pada ekstrak bawang merah $60 \%$ ditemukan tidak adanya perbedaan dengan ekstrak bawang putih $30 \%$ dan $40 \%$. Sedangkan pada ekstrak bawang merah $70 \%$ ditemukan tidak adanya perbedaan dengan ekstrak bawang putih $40 \%$ dan $50 \%$.

\section{PEMBAHASAN}

\section{Pengukuran Diameter Zona Hambat}

Hasil yang diperoleh dari ekstrak bawang merah tidak mempunyai daya hambat pada konsentrasi 30\%, 40\%, 50\%, dan $60 \%$ sedangkan pada konsentrasi $70 \%$ didapatkan zona hambat dengan diameter yaitu 6,8 mm. Ekstrak bawang putih memiliki daya hambat paling baik pada konsentrasi $70 \%$ dengan zona hambat sebesar $8 \mathrm{~mm}$. Namun hasil ini masih terlalu rendah apabila dibandingkan dengan kontrol positif. Hal ini dapat terjadi karena Artinya baik ekstrak bawang merah maupun bawang puth masih belum mampu menghambat pertumbuhan bakteri S. dysentriae. Bakteri Gram negatif diketahui memiliki selubung yang bersifat kompleks sehingga dapat mencegah agen antimikroba untuk masuk melalui dinding selnya [13]. Penelitian dari Lekhsmi tahun 2015 dengan menggunakan ekstrak bawang putih (Allium sativum) dan bawang merah (Allium cepa L) pada bakteri Gram positif (Staphilococcus sp) dan beberapa bakteri Gram negatif (Klebsiella sp, E. coli, Proteus sp, Pseudomonas sp) menghasilkan zona hambat lebih baik pada bakteri Gram positif (Staphilococcus sp ) dengan diameter zona hambat $17.67 \mathrm{~mm}$ dibandingkan dengan bakteri Gram negatif (Klebsiella sp, E coli, Proteus sp, Pseudomonas sp) ) diameter zona hambat diantara $10.33-12.83 \mathrm{~mm}$ pada konsentrasi tertinggi ekstrak bawang putih (Allium sativum) dengan pelarut air. Penelitian yang lainnya menggunakan ekstrak bawang merah (Allium cepa L) pada bakteri Staphilococcus sp dan E. coli didapatkan hasil $9,5 \mathrm{~mm}-12,16 \mathrm{~mm}$ pada bakteri Gram positif ( Staphilococcus sp ) sedangkan pada bakteri $E$. coli tidak didapatkan zona hambat pada konsentrasi tertinggi yaitu $80 \%$ [14].

\section{Konsentrasi Hambat Minimum (KHM)}

Pada penelitian ini tidak didapatkan KHM hal ini dikarenakan ekstrak yang didapatkan pada penelitian ini terlihat keruh, sehingga tidak dapat menilai kekeruhan media karena adanya pertumbuhan bakteri. kekeruhan pada ekstrak. Pada penelitian sebelumya yang dilakukan Amin pada tahun 2004 didapatkan pada ekstrak segar dari bawang putih dan ekstrak bawang merah pada bakteri Shigella $s p$ didapatkan KHM masing masing ekstrak pada konsentrasi $>20 \mathrm{mg} / \mathrm{ml}$.

\section{Konsentrasi Bunuh Minimum (KBM)}

Tidak ditemukannya KBM pada penelitian ini karena pada ekstrak bawang merah maupun bawang puth tertinggi masih terhitung adanya koloni bakteri pada colony counter. Pada beberapa penelitian sebelumya bahwa KBM pada ekstrak etanol bawang puth terhadap beberapa bakteri seperti S. aureus, E.coli , S. pneumoniae, Paeruginosa didapatkan nilai KBM berturut turut pada konsentrasi 100 $\mathrm{mg} / \mathrm{ml}, \quad 150 \mathrm{mg} / \mathrm{ml}, 125 \mathrm{mg} / \mathrm{ml}$, dan 175 $\mathrm{mg} / \mathrm{ml}$. Hal ini mengindikasikan bahwa bawang putih memiliki potensial untuk dapat membunuh bakteri [15]. Pada penelitian yang dilakukan Amin tahun 2004 pada berbagai jenis bakteri didapatkan bahwa pada ekstrak bawang putih dan ekstrak bawang merah didapatkan hasil berturut turut $>20 \mathrm{mg} / \mathrm{ml}$. 
Pada penelitian yang dilakukan Upa sedikit zona hambat sehingga tidak dapat (2017) karena efek antibakteri pada menentukan kadar KBM dan KHM nya. ekstrak bawang putih yang menghasilkan

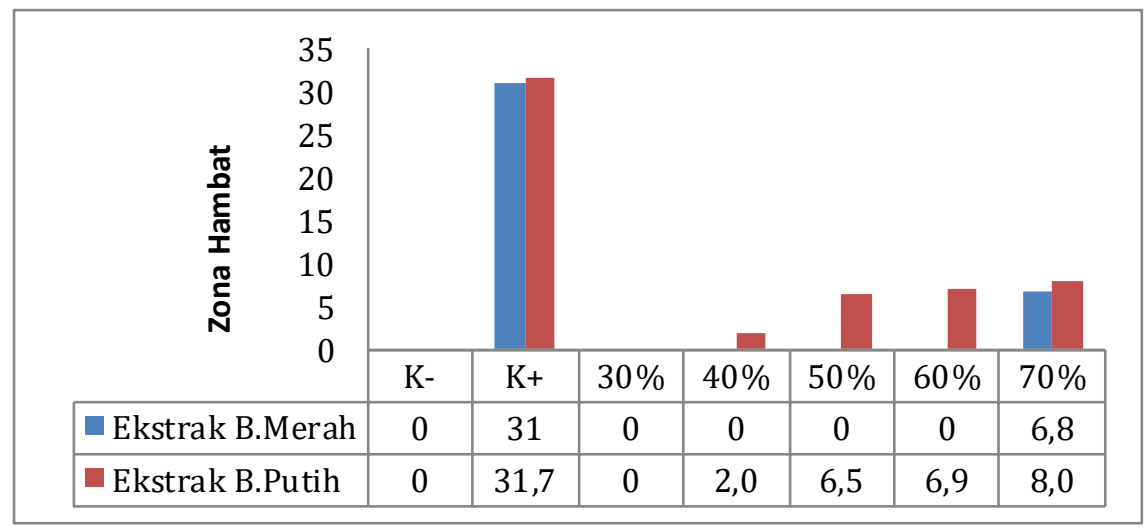

Gambar 1. Grafik Pengaruh Pemberian Ekstrak Bawang Merah dan Bawang Putih terhadap Diameter Zona Hambat

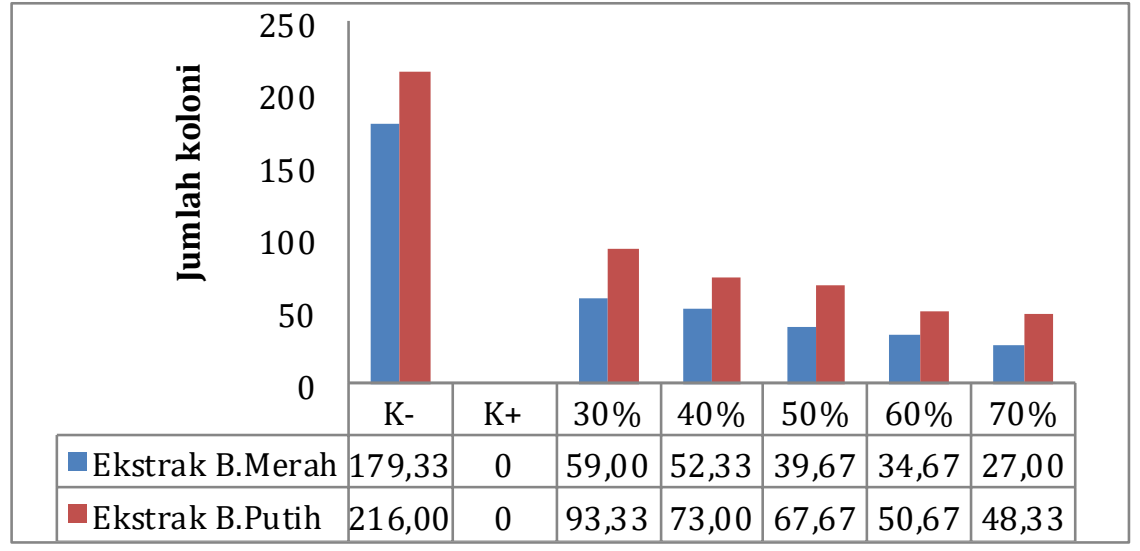

Gambar 2. Grafik Pengaruh Pemberian Ekstrak Bawang Merah dan Bawang Putihterhadap Konsentrasi Bunuh Minimal S. dysenteriae

Efek antibakteri pada ekstrak bawang merah (Allium cepa L) dan bawang putih (Allium sativum) ini dapat terjadi karena adanya kandungan fitokimia yang ada didalam bawang puth dan bawang merah. Pada bawang puth diketahui memiliki senyawa allisin terutama turunannya DADS (Diallyl disulfide) yang dapat membunuh bakteri dengan cara mengkontrol keadaan stress oksidatif dengan deaktivasi atupun mengikat agen pengoksidasi yang berbahaya, senyawa allisin ini juga dapat mengurangi viabilitas sel terhadap infeksi dari bakteri [10]. Pada ekstrak bawang merah senyawa fitokimia quercetin yaitu salah satu turunan dari senyawa flavanoid dapat merusak membran dan menginaktifasi protein ekstraseluller pada bakteri dengan membentuk kompleks irreversibel [5].

\section{KESIMPULAN}

1. Ekstrak Bawang Merah (Allium cepa L) mempunyai pengaruh dalam menghambat pertumbuhan bakteri $S$. dysenteriae dengan diameter zona hambat paling besar $6,8 \mathrm{~mm}$ pada konsentrasi $70 \%$.

2. Ekstrak Bawang Puth (Allium sativum) mempunyai pengaruh daalam 
menghambat pertumbuhan $S$. dysenteriae dengan rata-rata $8,35 \mathrm{~mm}$ pada konsentrasi $70 \%$.

3. Ekstrak Bawang Puth (Allium sativum) memiliki aktivitas antibakteri lebih baik dibandingkan dengan Ekstrak Bawang Bawang Merah (Allium cepa L) terhadap bakteri $S$. dysenteriae. Namun hasil ini tidak bermakna apabila dibandingkan dengan kontrol positif.

\section{SARAN}

Penelitian selanjutnya diharapkan dapat melakukan penelitan menggunakan bahan aktif yang ada didalam Bawang Merah (Allium cepa L) dan Bawang Putih (Allium sativum) dengan menggunakan metode lainnya.

\section{DAFTAR PUSTAKA}

[1] World Health Organization (Ed.), 2010. WHO recommendations on the management of diarrhoea and pneumonia in HIV-infected infants and children. World Health Organization, Departments of Child and Adolescent Health and Development $(\mathrm{CAH})$ and

[2] Jandu, N., Goldberg, M.B., 2013. Dysentery, in: Rosenberg, E., DeLong, E.F., Lory, S., Stackebrandt, E., Thompson, F. (Eds.), The Prokaryotes. Springer Berlin Heidelberg, Berlin, Heidelberg, pp. 309-321.

[3] Setiati S, A.I., Sudoyo AW, Stiyohadi B, Syam AF, 2014. Buku ajar ilmu penyakit dalam jilid III, VI. ed. InternaPublishing, Jakarta.

[4] Cornelissen, C.N., Fisher, B.D., Harvey, R.A., 2013. Microbiology, 3rd ed. ed, Lippincott's illustrated reviews. Lippincott Williams \& Wilkins Health, a Wolters Kluwer Company, Philadelphia.

[5] Orăşan, O., Oprean, R., Saplonţai-Pop, A., Filip, M., Carpa, R., Saroşi, C., Moldovan, M., Man, S.C., 2017. Antimicrobial activity and thiosulfinates profile of a formulation based on Allium cepa $L$. extract. Open Chem. 15.

[6] Santhosha, S.G., Jamuna, P., Prabhavathi, S.N., 2013. Bioactive components of garlic and their physiological role in health maintenance: A review. Food Bioscience 3, 59-74. https://oi.org/10.1016/j.fbio.2013.0 7.001

[7] Upa, Gyidian A.A., 2017. Uji Aktivitas Antibakteri Ekstrak Etanol Bawang Putih (Allium sativum) terhadap Pertumbuhan Bakteri Salmonella typhii dan Shigella dysenteriae. Nomor 2 volume 4.

[8] Guédon, E. \& Martin-Verstraete, I., 2006. Cysteine Metabolism and Its Regulation in Bacteria. Microbiol Monogr Springer-Verlag Berlin Heidelberg.

[9] Jaelani, 2007. Khasiat Bawang Merah. Yogyakarta: Kanisius.

[10] Simaremare, A. P. R., 2017. Perbedaan Aktivitas Antibakteri Ekstrak Tanaman Obat Bawang Merah Dan Bawang Putih Terhadap Bakteri Staphylococcus Aureus. Nommensen Journal of Medicine, pp. 14-19.

[11] Degirmencioglu, Nurcan., Irkin, Reyhan., 2009. Survival Of Some Microorganisms In The Presence of Onion (Allium Cepa L.) Extracts In Vitro. Polish Journal Of Food And Nutrition Sciences No. 59, 61-66,

[12] Torres, Medina. et al.,2017. Ultrasound Assisted Extraction for the Recovery of Phenolic Compounds from Vegetable Sources. Agronomy, 7(47).

[13] Abubakar, E.-m. M., 2009. Efficacy of crude extracts of garlic (Allium sativum Linn.) against nosocomial Escherichia coli ,Staphylococcus aureus, Streptococcus pneumoniea, and Pseudomonas aeruginosa. Journal of Medicinal Plants Research, 3(4), pp. 179-185. 
Perbandingan uji aktivitas antibakteri umbi bawang merah (Allium cepa I) dan umbi bawang putih (Allium sativum) terhadap pertumbuhan bakteri shigella dysenteriae

[14] Surono, A. S., 2013. Antibakteri Ekstrak Etanol Umbi Lapis Bawang Merah (Allium cepa L.) terhadap Pertumbuhan Staphylococcus aureus dan Escherichia coli. Jurnal Ilmiah Mahasiswa Universitas Surabaya, 2(1) 